\title{
Determination of Oil Change Interval for Gasoline Engines According to the Amount of Non- Ferrous Metals
}

\author{
Vladimír Hönig \\ Faculty of Agrobiology, Food and Natural Resources, Department of Chemistry, Czech University of Life Sciences Pra- \\ gue, Kamýcká 129, 165 21, Prague 6 - Suchdol, Czech Republic, E-mail: honig@af.czu.cz
}

Friction is closely related to every moving machine and fundamentally affects efficiency and service life. Wear tracking of moving and non-moving parts of the engine mechanism is important for expressing the wear trend. The wear and tear trend is specific for gasoline engines in urban traffic. The increase in the number of abrasive non-ferrous particles $(\mathrm{Al}, \mathrm{Cu}, \mathrm{Ni}, \mathrm{Cr}, \mathrm{Sn}, \mathrm{Si})$ is monitored in Škoda Octavia vehicles. The statistical evaluation of nomogram the wear and the determination of the optimum oil change interval of a vehicle group with sparkignition engines are performed for individual non-ferrous particles. The main aim of the article is to propose and verify the method of determination of the optimal oil change interval using Atomic Absorption Spectroscopy, Thin Layer Chromatography and using limit values of discriminatory analysis. On the basis of the results of the analyses, it is clear that the oil change interval by the manufacturer is inadequate and the oil level must be monitored.

Keywords: Thin Layer Chromatography, Atomic Absorption Spectroscopy, Engine Oil, Wear Particles, Discriminant Analysis

\section{Ackowledgement}

The article was edited under the financial support of project CIGA CULS Prague 20173001 - Utilization of butanol in compression ignition engines of generators.

\section{References}

[1] VESELÁ, K.., PEXA, M., MǍ̌íK, J. (2014). The effect of biofuels on the quality and purity of engine oil. Agronomy Research, Vol. 12, No. 2, pp. 425 - 430, Estonian Agricultural University. Estonia.

[2] ALEŠ, Z., PEXA, M., PAVLŮ, J. (2012). Tribotechnical diagnostics of agricultural machines, Engineering for Rural Development conference Jelgava, 24.-25.05.2012, [online]. [cit.2014-05.01] Available at www: http://www. http://tf.llu.lv.

[3] MIHALČOVÁ, J., HEKMAT, H. (2008). Tribotechnická diagnostika v prevádzke použitých olejov I. metódy hodnotenia častíc opotrebovania v olejoch, Chemické listy Vol. 102, pp. 358 - 362. Czech Society of Chemical Engineering, Prague, Czech Republic.

[4] Ministry of Defence CZ. (2007). Instruction for Tribodiagnostics of Engines, Gear and Hydraulic Systems, No. 79: 27/2007:3042, Logistics Division. Prague, Czech Republic.

[5] PAVLŮ, J., HÖNIG, V., ALEŠ, Z., CHOTĚBORSKÝ, R. (2016). Tribodiagnostic Analysis of Motor oil after Failure of Turbocharger of Combustion Engine, Manufacturing Technology, Vol. 16, No. 5, pp. 1115-1122, J. E. Purkyne University in Ústí nad Labem nad Labem. Czech Republic.

[6] HÖNIG, V., MIHOLOVÁ, D., ORSÁK, M. (2014). Measurement of Wear Metals in Engine Oils by Atomic Absorption Spektrometry Method. Manufacturing Technology, Vol. 14, No. 3, PP. 317 - 322, J. E. Purkyne University in Ústí nad Labem nad Labem. Czech Republic.

[7] HÖNIG, V., HROMÁDKO, J. (2014). Possibilities of using vegetable oil to power diesel engines as well as their impact on engine oil, Agronomy Research Vol. 12, No. 8, pp. 323 - 332. Estonian Agricultural University. Estonia.

[8] HÖNIG, V., SMRČKA, L., HORNÍČKOVÁ, Š. (2014). Application of discriminant analysis in monitoring the wear particles in the engine oil. Manufacturing Technology, Vol. 14, No. 3, pp. 322 - 326, J. E. Purkyne University in Ústí nad Labem nad Labem. Czech Republic.

[9] HÖNIG, V., ORSÁK, M. (2016). Wear of Engine Oils Using Gaseous Fuels, Manufacturing Technology, Vol. 16, No. 5, pp. 923-927, J. E. Purkyne University in Ústí nad Labem nad Labem. Czech Republic.

[10] PEXA, M., ALEŠ, Z., PAVLŮ, J., ČEDÍK, J. (2015). Analysis of Wear Particles Morphology of Machine Parts Based on Aluminium. Manufacturing Technology, Vol. 15, No. 4, pp. 664 - 670, J. E. Purkyne University in Ústí nad Labem nad Labem. Czech Republic. 
[11] ALEŠ, Z., PAVLŮ. J., SVOBODOVÁ, J., PEXA, M. (2016). Use of Microscopy for Morphology Analysis of Wear Particles Generated in the Fuel Systems of Internal Combustion Engine, Manufacturing Technology, Vol. 16, No. 5, pp. 849-853, J. E. Purkyne University in Ústí nad Labem nad Labem. Czech Republic.

[12] HÖNIG, V. (2015). Morphological Classification of Nonferrous Wear Particles in Engine Oil Using Pherrographical Method. Manufacturing Technology, Vol. 15, No. 4, pp. 530 - 534, J. E. Purkyne University in Ústí nad Labem nad Labem. Czech Republic.

\section{Paper number: M2017128}

Copyright $\odot$ 2017. Published by Manufacturing Technology. All rights reserved. 